\title{
Współczesne wykorzystanie przez bobra europejskiego Castor fiber antropogenicznie przekształconych dolin rzecznych (przykłady z Równiny Opolskiej i Wyżyny Woźnicko-Wieluńskiej)
}

\author{
Contemporary adaptation of anthropogenically-transformed \\ river valleys by European beavers Castor fiber \\ (examples from Poland's Opole Plain and Woźniki-Wielun Upland)
}

\author{
MARIA FAJER, IRENEUSZ MALIK, JAN MACIEJ WAGA, \\ MALGORZATA WISTUBA, BEATA WOSKOWICZ-ŚLĘZAK \\ Wydział Nauk o Ziemi, Uniwersytet Śląski, \\ 41-200 Sosnowiec, ul. Będzińska 60; \\ maria.fajer@us.edu.pl, irekgeo@wp.pl, jan.waga@us.edu.pl, \\ malgorzatawistuba@gazeta.pl, beata.woskowicz-slezak@us.edu.pl
}

\begin{abstract}
Zarys treści. W pracy przedstawiono typowe przypadki konstruktorskiej działalności bobrów w dolinach Małej Panwi i Liswarty oraz ich dopływów. Przeprowadzone badania wskazują, że bobry chętniej zasiedlają małe rzeki 3-4 rzędu niż rzeki główne. Najliczniejsze ślady działalności bobrów zaobserwowano na zalesionych odcinkach dolin Leńcy i Olszynki, gdzie gryzonie przekształciły 28-35\% długości koryt rzecznych. Interesującym, niemal symbolicznym przypadkiem jest „naprawa” przez bobry grobli ziemnych starych stawów antropogenicznych i utworzenie w ich miejscu stawów bobrowych.
\end{abstract}

Słowa kluczowe: bobry, tamy bobrowe, dawne obiekty hydrotechniczne, Mała Panew, Liswarta.

\section{Wprowadzenie}

W dolinach rzecznych w Polsce, podobnie jak w wielu miejscach w Europie Środkowej, widoczne są pozostałości dawnych systemów hydrotechnicznych wykorzystywanych przez młyny zbożowe, kuźnice i tartaki (m.in. Kukulak, 2000; Cech, 2004; Podgórski, 2004; Witek, 2012; Fajer, 2014; Malik i inni, 2015). Po wprowadzeniu w XIX w. do użytku maszyny parowej, a potem elektryczności, zmalało znaczenie wody jako głównego źródła napędu. Skutkowało to stopniową likwidacją zakładów produkcyjnych usytuowanych ze względów energetycznych 
nad rzekami. Dawne osady zlokalizowane w dnach dolin rzecznych wyludniały się, a obiekty hydrotechniczne niszczały.

W czasach poprzedzających intensywny rozwój przemysłu korzystającego z energii rzek i towarowej gospodarki leśnej, integralną częścią ekosystemów wodnych Eurazji i Ameryki Północnej były bobry (Castor fiber w Europie, Castor canadensis w Ameryce Północnej) zasiedlające jeziora, rzeki i ich opuszczone koryta (Pollock i inni, 2003; Halley i inni, 2012). Bóbr jest drugim po człowieku znaczącym czynnikiem powodującym zmiany krajobrazu den dolin rzecznych. Dowody na koegzystencję obu gatunków w środowisku sięgają mezolitu (Coles i Orme, 1983; Bagniewski, 1990; Bejenaru i inni, 2015). Zasiedlając wybrane terytorium bobry, podobnie jak człowiek, przystosowują je do swoich potrzeb. Z tego powodu w literaturze są często nazywane „inżynierami ekosystemów” (Wright i inni, 2002; Rosell i inni, 2005; Gibson i Olden, 2014). Bez wątpienia tamy bobrowe były inspiracją dla konstrukcji hydrotechnicznych człowieka (Błędzki i inni, 2011). Bobry z powodzeniem adaptują się do środowiska zmienionego przez człowieka i coraz częściej zasiedlają nie tylko tereny leśne i rolnicze, ale także bezpośrednie sąsiedztwo szlaków komunikacyjnych, tereny sąsiadujące z osadami ludzkimi, a nawet miasta (Bereszyński i Homan, 2007; Janiszewski i Misiukiewicz, 2012).

Na początku XX w. w wielu krajach Europy bóbr prawie wyginął (Halley i inni, 2012; Gibson i Olden, 2014). Rozwój osadnictwa, postępujące wylesienia, a potem regulacja koryt rzecznych i intensywne prace melioracyjne spowodowały ograniczenie ich siedlisk. Procesu eliminacji bobra dopełniły polowania na tego ssaka.

W Polsce, po II wojnie światowej zachowało się zaledwie kilka stanowisk bobra europejskiego w północno-wschodniej części kraju. W połowie lat 1970. rozpoczęto odbudowywanie populacji tych zwierząt i reintrodukcję w wybrane doliny rzeczne (Żurowski, 1992; Dzięciołowski i Gozdziewski, 1999). Na przełomie XX i XXI w. prowadzono coraz szerzej zabiegi czynnej ochrony przyrody. Za sprawą ochrony gatunkowej, reintrodukcji i translokacji bobra w różne części Polski, jego populacja wzrosła (Dzięciołowski, 2004; Czech, 2010).

Według danych zamieszczonych w Roczniku Statystycznym w 2015 r. liczebność populacji bobrów w Polsce przekraczała 100000 sztuk, jednak zdaniem specjalistów dane te są zawyżone (Dzięciołowski i Gozdziewski, 1999; Dzięciołowski, 2004; Czech, 2005, 2010; Janiszewski i Misiukiewicz, 2012).

Reintrodukcja bobrów w doliny Małej Panwi i Liswarty prowadzona była w latach 1990. (Mała Panew - 1994, Liswarta - 1995 r.). Bobry zastały tam przekształcony przez człowieka system rzeczny - liczne budowle ziemne, przepusty drogowe i zbiorniki wodne o różnym przeznaczeniu, często z umocnionymi brzegami. Gryzonie rozpoczęły wędrówkę i adaptację siedlisk do swoich potrzeb. Tam, gdzie ze względów gospodarczych nie było potrzeby eliminacji stanowisk bobrowych, zwierzętom pozwolono urządzić sobie „domy”, gdy zaś bobry 
zagrażały obiektom użytkowanym przez człowieka, np. szlakom kolejowym, były translokowane w inne miejsca.

W trakcie badań prowadzonych nad Małą Panwią (Ciszewski i inni, 2005; Malik, 2006; Malik i inni, 2015) i Liswartą (Fajer, 2014) zauważono, że w przekształconych odcinkach koryt rzecznych i w rowach melioracyjnych oraz w obrębie dawnych systemów hydrotechnicznych często występują budowle bobrów. Podjęto badania mające na celu ustalenie:

- jak liczne są stanowiska bobrów, szczególnie w obrębie i w sąsiedztwie dawnych i współczesnych obiektów hydrotechnicznych,

- w jaki sposób bobry „zagospodarowują” te obiekty,

- jakie są skutki działalności bobrów w środowisku badanych dolin rzecznych.

\section{Obszar badań}

Badania prowadzono w dolinach Małej Panwi i jej dopływu Rowu Kokockiego oraz nad Liswartą i jej dopływami Leńcą i Olszynką (ryc. 1, tab. 1).

Mała Panew i Liswarta należą do dorzecza Odry. Ich graniczące ze sobą zlewnie rozdziela niski próg strukturalny (Gilewska, 1972) (ryc. 1A). W większości są to tereny zajęte przez piaszczyste lub piaszczysto-gliniaste osady glacjogeniczne oraz eoliczne piaski pokrywowe i wydmy (Szczypek, 1977). Aluwia są wykształcone jako piaski różnoziarniste (Malik, 2004; Fajer, 2004). Mała Panew i górna Liswarta mają szerokie dna dolin - od 120 do $600 \mathrm{~m}$. W ich obrębie równiny zalewowe wznoszą się na wysokość od 0,5 do $2 \mathrm{~m}$ nad poziomy rzek. W silnie meandrującym korycie Małej Panwi występują liczne piaszczyste wyspy śródkorytowe (Malik, 2008).

Obie rzeki cechują się wyrównanym reżimem hydrologicznym o małych amplitudach przepływów, z wezbraniami wiosennymi i letnimi oraz zasilaniem gruntowo-deszczowo-śnieżnym. Średnie roczne temperatury w okolicy wynoszą 7-8 ${ }^{\circ} \mathrm{C}$, a roczne sumy opadów 600-700 mm (Dynowska, 1971).

W zlewniach Małej Panwi i Liswarty dominuje leśno-rolny typ użytkowania ziemi. Zwarte kompleksy leśne zajmują duże powierzchnie. Lokalnie lesistość tamtejszych gmin wynosi od 60\% do ponad 70\% (Statystyczne Vademecum..., 2015). W dolinie Małej Panwi dominuje gospodarczy las sosnowy, a tylko w wąskich pasach wzdłuż cieków występują płaty łęgu jesionowo-olszowego (Circaeo-Alnetum), łęgu topolowo-wierzbowego (Salici Populetum) oraz olsu (Ribo nigri-Alnetum) (Malik, 2008). W górnym odcinku Liswarty rosną lasy łęgowe (Plan ochrony...). Na odcinkach Leńcy i Olszynki objętych szczegółowymi badaniami występuje las mieszany wilgotny z przewagą sosny zwyczajnej i domieszką dębu, świerka, brzozy i buka oraz ols z przewagą olszy, brzozy i sosny (Plan urzadzenia lasu...). Znaczne powierzchnie w dolinach zajmują łąki i pastwiska. Część gruntów rolnych jest obecnie nieużytkowana i podlega sukcesji w kierunku lasu. 

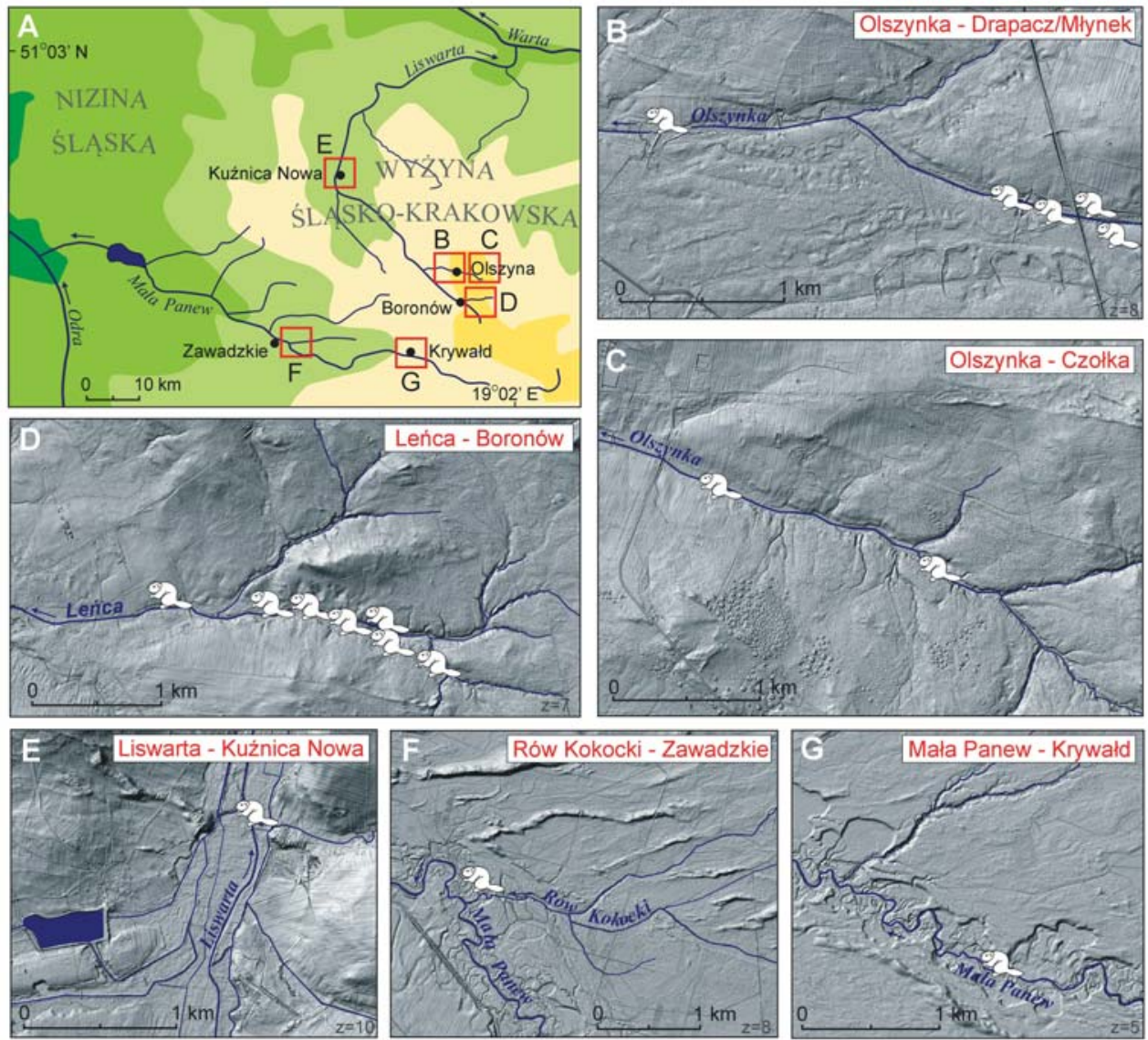

Ryc. 1. Położenie obszarów badań: A - w południowej Polsce, w dolinach Małej Panwi i Liswarty; stanowiska bobrowe nad rzekami: B, C - Olszynką, D - Leńcą, E - Liswartą, F - Rowem Kokockim, G - Małą Panwią

Location of research areas: A - in southern Poland, in the Mała Panew and Liswarta Valleys;

beaver sites on the watercourses known as: B, C - the Olszynka, D - the Leńca,

E - the Liswarta, F - the Rów Kokocki (drain), G - the Mała Panew

Opracowanie własne, podobnie pozostałe ryciny / Authors' own elaboration, as the remaining figures.

\section{Antropogeniczne przekształcenia koryt rzecznych w zlewniach Małej Panwi i Liswarty}

Presja antropogeniczna na środowisko dolin rzecznych badanego obszaru związana była głównie z wykorzystaniem energii wodnej oraz ich rolniczym użytkowaniem. Nad Małą Panwią i Liswartą oraz dopływami od XIV do połowy XIX w. działały małe kuźnice żelaza. Wykorzystywały one energię wody płynącej, miejscowe złoża rud żelaza, a do opału drewno z pobliskich lasów. Zakła- 
Tabela 1. Cechy badanych cieków

Features of the discussed watercourses

\begin{tabular}{|c|c|c|c|c|c|c|c|}
\hline $\begin{array}{c}\text { Ciek } \\
\text { Waterco- } \\
\text { urse }\end{array}$ & $\begin{array}{c}\text { Długość } \\
\text { cieku } \\
\text { Water- } \\
\text { course } \\
\text { length } \\
(\mathrm{km})\end{array}$ & $\begin{array}{c}\text { Rząd } \\
\text { cieku } \\
\text { Water- } \\
\text { course } \\
\text { order }\end{array}$ & $\begin{array}{l}\text { Szerokość } \\
\text { koryta na } \\
\text { badanym } \\
\text { odcinku } \\
\text { Watercourse } \\
\text { width on } \\
\text { study reach } \\
\text { (m) }\end{array}$ & $\begin{array}{l}\text { Głębo- } \\
\text { kość } \\
\text { koryta } \\
\text { Water- } \\
\text { course } \\
\text { depth } \\
\text { (m) }\end{array}$ & $\begin{array}{l}\text { Spadek } \\
\text { koryta } \\
\text { Channel } \\
\text { slope } \\
(\mathrm{m} \\
\left.\mathrm{km}^{-1}\right)\end{array}$ & $\begin{array}{c}\text { Cechy koryta } \\
\text { Channel features }\end{array}$ & $\begin{array}{l}\text { Użytkowanie } \\
\text { terenu } \\
\text { Land use }\end{array}$ \\
\hline $\begin{array}{l}\text { Mała } \\
\text { Panew }\end{array}$ & 129,1 & 2 & 12 & $0,9-1,5$ & 1,6 & $\begin{array}{l}\text { Naturalne, dno } \\
\text { piaszczysto-gli- } \\
\text { niaste }\end{array}$ & Las \\
\hline $\begin{array}{l}\text { Rów } \\
\text { Kokocki }\end{array}$ & 13,9 & 3 & $2-4$ & $0,3-0,6$ & 2,2 & $\begin{array}{l}\text { Uregulowane, } \\
\text { dno piaszczyste }\end{array}$ & Las \\
\hline Liswarta & 96 & 3 & 10 & $0,6-0,8$ & 1,8 & $\begin{array}{l}\text { Uregulowane, } \\
\text { dno piaszczyste }\end{array}$ & $\begin{array}{l}\text { Łąki i pastwiska, } \\
\text { szpalery drzew } \\
\text { wzdłuz koryta }\end{array}$ \\
\hline Leńca & 6,8 & 4 & $1-3$ & $0,3-0,5$ & 5,2 & $\begin{array}{l}\text { Naturalne, dno } \\
\text { piaszczysto-gli- } \\
\text { niaste }\end{array}$ & Las \\
\hline Olszynka & 10,9 & 4 & $1-3$ & 0,5 & 6,7 & $\begin{array}{l}\text { Koryto uregulo- } \\
\text { wane i pogłębio- } \\
\text { ne, dno piasz- } \\
\text { czyste }\end{array}$ & $\begin{array}{l}\text { Las, łąki } \\
\text { i pastwiska } \\
\text { częściowo } \\
\text { użytkowane }\end{array}$ \\
\hline
\end{tabular}

Opracowanie własne na podstawie badań terenowych i map topograficznych w skali 1:10 000. Authors' own compilation based on field research and topographic maps, scale 1:10 000.

dy te przestały funkcjonować wraz z rozkwitem hutnictwa opartego na koksie (Popiołek, 1965). Po II wojnie światowej zakończyła działalność większość młynów wodnych (młynów zbożowych i tartaków). W dnach dolin zachowały się relikty budowli hydrotechnicznych, fragmenty starych kanałów wodnych kuźnic i młynów zbożowych oraz niecki stawów i relikty grobli (Fajer, 2014; Malik i inni, 2015). Niektóre z tych obiektów uległy częściowej naturalizacji. Stawy, które przetrwały do dziś lub zostały odbudowane pełnią funkcję hodowlaną lub retencyjno-rekreacyjną.

Przekształcenia systemu wodnego Małej Panwi i Liswarty związane z gospodarką rolną i leśną polegały głównie na odwodnieniu użytkowanych terenów. Koryta rzeczne w większości zostały uregulowane, a równiny zalewowe zmeliorowane. Prace te prowadzono od początku XIX w. do połowy lat 1990., szczególnie intensywnie w połowie XX w. (Fajer, 2003).

Poprzez melioracje w lasach zwiększono obszary przydatne do uprawy sosny. Górne odcinki cieków leśnych i śródpolnych zostały przekształcone w rowy. 
Wyprostowano ich bieg, pogłębiono koryta, a brzegi umocniono faszyną. Doszło do obniżenia poziomu wód powierzchniowych i gruntowych. Materiałem ziemnym pochodzącym z regulacji i pogłębiania koryt zasypano starorzecza, a także lokalnie nadbudowano równinę zalewową oraz brzegi cieków tworząc swego rodzaju wały przykorytowe (Fajer, 2003).

\section{Materiały i metody badań}

Do określenia lokalizacji i przeznaczenia dawnych obiektów hydrotechnicznych, wykorzystano archiwalne materiały kartograficzne z XIX i XX w. Przeanalizowano treść niemieckich i polskich map topograficznych, mapę Gilly'ego w skali 1:150 000 z lat 1802-1803 i Reymanna w skali 1:200 000 z lat 1832-1870 oraz mapy topograficzne w skali 1:25 000, tzw. Messtischblatt, z lat 1870-1889. Wykorzystano także Mapę Kwatermistrzostwa w skali 1:126 000 z lat 1839-1843 oraz mapy topograficzne WIG w skali 1:25 000 z lat 1929-1939.

Do oceny efektów działalności bobrów wytypowano 6 odcinków cieków o długości od 0,5 do $7 \mathrm{~km}$, zarówno obecnie zamieszkanych przez bobry, jak i takich, które zostały przez nie niedawno opuszczone. Do ustalenia zmian w rozmieszczeniu tam i stawów bobrowych oraz oceny zasięgu ich oddziaływania wykorzystano ortofotomapy z lat 1996, 2003, 2009 (http://mapy.orsip.pl/imap) i 2012 (http://geoportal.gov.pl), a także wywiady z właścicielami/gospodarzami terenów, na których osiedliły się zwierzęta. W formie rysunków, fotografii i opisów udokumentowano wygląd i rozmieszczenia tam, stawów bobrowych oraz innych śladów obecności gryzoni. Sporządzono szkice geomorfologiczne w skali 1:10 000 obszarów badań szczegółowych oraz wygenerowano wizualizacje z numerycznych modeli terenu opartych na danych $\mathrm{z}$ lotniczego skaningu laserowego (LiDAR), uzyskanych z CODGiK. Badania terenowe prowadzono od lipca do grudnia $2015 \mathrm{r}$.

\section{Wyniki badań}

W trakcie badań rozpoznano różne przypadki kolonizowania przez bobry koryt cieków i wykorzystywania przez nie pozostałości obiektów hydrotechnicznych. Rozpoznano 12 stanowisk bytowania bobra, a w ich obrębie 30 tam bobrowych (różnych rozmiarów, zachowanych w różnym stanie) oraz 14 stawów i niewielkich rozlewisk. Poniżej przedstawiono siedem typowych przypadków budowli bobrowych, które zestawiono również w tabeli 2.

\section{Przypadek 1: Wznoszenie tam bobrowych w korycie uregulowanej rzeki}

W dolinie Olszynki od końca XVIII w. do lat 1930. były 2 stawy młyńskie i 6 rybnych. W nieistniejącej już osadzie Młynek zachowały się groble stawu młyńskiego i trzech małych stawów rybnych. Terasa zalewowa oraz dna dawnych 
Tabela 2. Stanowiska badawcze wraz z ogólną charakterystyką analizowanych obiektów

Research sites with general description of the analyzed objects

\begin{tabular}{|c|c|c|c|c|c|}
\hline \multirow{2}{*}{$\begin{array}{l}\text { Stanowi- } \\
\text { sko } \\
\text { Site }\end{array}$} & \multirow{2}{*}{$\begin{array}{c}\text { Przypadek } \\
\text { opisany } \\
\text { w tekście } \\
\text { The case } \\
\text { described } \\
\text { in the } \\
\text { article }\end{array}$} & \multicolumn{2}{|c|}{$\begin{array}{l}\text { Lokalizacja stanowiska } \\
\text { Site location }\end{array}$} & \multicolumn{2}{|c|}{$\begin{array}{l}\text { Obiekty hydrotechniczne oraz tamy i stawy bobrowe z podaniem ich wymiarów } \\
\text { Hydrotechnical objects with beaver ponds and dams and their sizes }\end{array}$} \\
\hline & & $\begin{array}{l}\text { Rzeka/ciek } \\
\text { River/stre- } \\
\text { am }\end{array}$ & $\begin{array}{l}\text { Współrzędne geogra- } \\
\quad \text { ficzne N; E } \\
\text { Geographical coordi- } \\
\text { nates Lat. N; Lon. E }\end{array}$ & $\begin{array}{l}\text { Obiekt hydrotechniczny } \\
\text { L- długość, W - szerokość, } \\
\text { H - wysokość }\end{array}$ & $\begin{array}{l}\text { Tamy i stawy bobrowe } \\
\text { L- długość tamy, H - średnia wysokość tamy, } \\
\text { A - powierzchnia stawu }\end{array}$ \\
\hline \multicolumn{6}{|c|}{ Zlewnia Małej Panwi / Mała Panew catchment } \\
\hline Zawadzkie & 7 & $\begin{array}{l}\text { Rów } \\
\text { Kokocki }\end{array}$ & $50^{\circ} 36^{\prime} ; 18^{\circ} 30^{\prime}$ & $\begin{array}{l}\text { Przerwana grobla (L } 83 \text { m, H 2,5) daw- } \\
\text { nego stawu }\end{array}$ & $\begin{array}{l}\text { Tama (L } 8 \mathrm{~m}, \mathrm{H} \text { 1,5 m) wypełniająca wyrwę w starej grobli } \\
\text { i staw }\left(\mathrm{A} 7300 \mathrm{~m}^{2}\right) ; 2 \text { tamy w korycie potoku powyżej stawu }\end{array}$ \\
\hline Krywałd & 3 & $\begin{array}{l}\text { Mała } \\
\text { Panew }\end{array}$ & $50^{\circ} 35^{\prime} ; 18^{\circ} 46^{\prime}$ & $\begin{array}{l}\text { Kanał wodny (L } 420 \text { m, W } 4 \text { m) nieist- } \\
\text { niejącej fryszerki }\end{array}$ & Relikty tamy (?) bobrowej; żerowisko bobrów \\
\hline \multicolumn{6}{|c|}{ Zlewnia Liswarty / Liswarta catchment } \\
\hline Boronów & 7 & Leńca & $50^{\circ} 40^{\prime} ; 18^{\circ} 57^{\prime}$ & $\begin{array}{l}\text { Przerwana grobla stawu retencyjnego } \\
\text { (L } 24 \mathrm{~m}, \mathrm{~W} 1 \mathrm{~m} \text { ) }\end{array}$ & 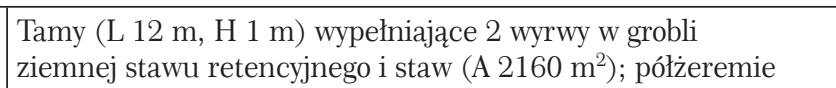 \\
\hline Drapacz & 4 & Olszynka & $50^{\circ} 43^{\prime} ; 18^{\circ} 49^{\prime}$ & Staw retencyjno-rekreacyjny (1,8 ha) & Nora w brzegu stawu ukryta za płytami betonowymi \\
\hline Młynek 1 & 1 & Olszynka & $50^{\circ} 43^{\prime} ; 18^{\circ} 51^{\prime}$ & $\begin{array}{l}\text { Pozostałości osady młyńskiej: grobla } \\
\text { i misa dawnego stawu młyńskiego, } \\
\text { uregulowane koryto rzeki }\end{array}$ & 6 tam (L 3-4 m, H 0,8-1 m) i rozlewiska \\
\hline Młynek 2 & 5 & Olszynka & $50^{\circ} 43^{\prime} ; 18^{\circ} 51^{\prime}$ & $\begin{array}{l}\text { Groble i misy } 3 \text { leśnych stawów rybnych } \\
\left(450 \text { i } 1380 \mathrm{~m}^{2}\right) \text {, uregulowane koryto } \\
\text { rzeki }\end{array}$ & $\begin{array}{l}\text { Tama (L } 50 \mathrm{~m}, \mathrm{H} \text { 1,3 m) i rozlewisko powstałe z zalania } \\
\text { mis dawnych stawów antropogenicznych i terasy zalewowej } \\
\left(\mathrm{A} 2400 \mathrm{~m}^{2}\right)\end{array}$ \\
\hline Olszyna & 2 & Olszynka & $50^{\circ} 42^{\prime} ; 18^{\circ} 53^{\prime}$ & Przepusty drogowe & $\begin{array}{l}6 \text { tam }(\mathrm{L} 2-3 \mathrm{~m}, \mathrm{H}-0,8 \mathrm{~m}) \text { i } 7 \text { rozlewisk (A od } 83 \text { do } 522 \mathrm{~m}^{2} \text {, } \\
\left.\text { łącznie } 8370 \mathrm{~m}^{2}\right)\end{array}$ \\
\hline Czołka & 6 & Olszynka & $50^{\circ} 42^{\prime} ; 18^{\circ} 54^{\prime}$ & $\begin{array}{l}\text { Zbiornik leśny z ujęciem wody do celów } \\
\text { przeciwpożarowych, koryto uregulowane }\end{array}$ & $\begin{array}{l}2 \text { tamy (L } 5 \text { do } 15 \mathrm{~m}, \mathrm{H} \text { 1-1,5 m) i rozlewisko }\left(\mathrm{A} 8360 \mathrm{~m}^{2}\right) \\
\text { półżeremie w brzegu zbiornika przeciwpożarowego }\end{array}$ \\
\hline $\begin{array}{l}\text { Kuźnica } \\
\text { Nowa }\end{array}$ & 3 & Liswarta & $50^{\circ} 52^{\prime} ; 18^{\circ} 38^{\prime}$ & $\begin{array}{l}\text { Kanał młynówki (L 1,2 km, W 2-3 m) } \\
\text { nieczynnego młyna wodnego }\end{array}$ & $\begin{array}{l}\text { Tama (L 3,5, H 1,0) i mały staw }\left(\text { A } 39 \mathrm{~m}^{2}\right), 30 \text { m powyżej ujścia } \\
\text { młynówki do rzeki, nora w brzegu młynówki; żerowisko bobrów } \\
\text { wzdłuż kanału i koryta rzeki }\end{array}$ \\
\hline
\end{tabular}


stawów i ich groble porosły drzewami i zaroślami wierzbowymi typowymi dla zbiorowisk łęgowych i olsowych. Wiek drzew oceniono na 20 do 80 lat. Koryto cieku jest tam uregulowane i pogłębione, w przekroju ma kształt trapezu. Około $50 \mathrm{~m}$ poniżej dawnych stawów rybnych bobry przegrodziły szerokie na 3-4 m koryto Olszynki tamą o wysokości $1 \mathrm{~m}$ (ryc. 2). Gromadzona powyżej tamy woda przelała się jednak przez obniżenia w wałach przykorytowych na terasę zalewową (ryc. 2C). Na powierzchni tej terasy, po obu stronach potoku bobry zbudo-
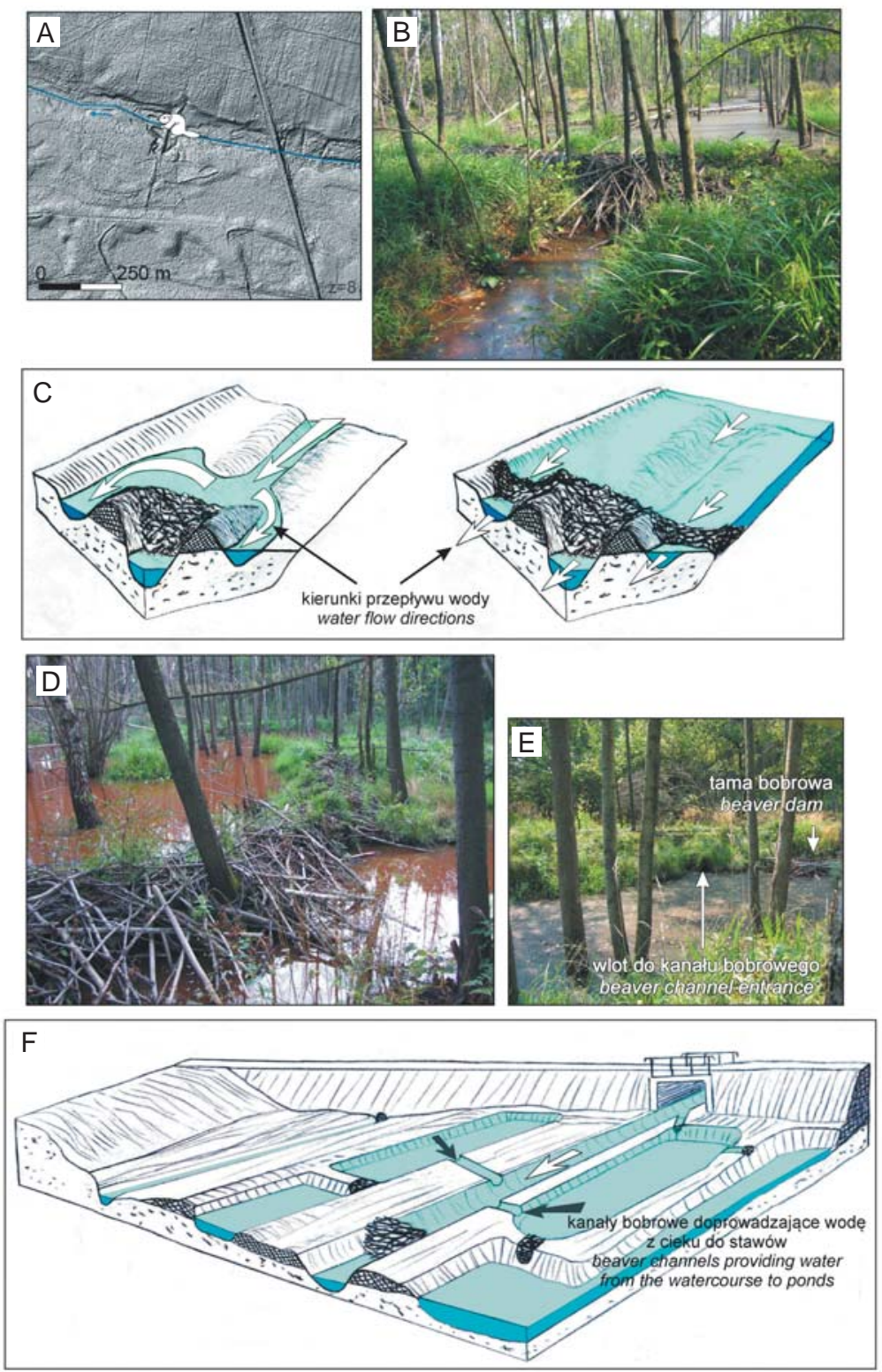
wały 2 łukowato biegnace tamy, łączące wały przykorytowe ze zboczami teras nadzalewowych, a następnie jeszcze nadbudowały całą tamę do maksymalnej wysokości 1,3 m (ryc. 2C). Zalaniu uległo całe dno doliny o szerokości około 50 m. W położonym niżej odcinku koryta bobry zbudowały jeszcze 3 tamy o wysokości 0,5-1 m. Na brzegach koryta widoczne są kanały transportowe, przy których zwierzęta zgromadziły ścięte gałęzie. Krótkie kanały (2-3 m) są suche, natomiast dłuższe i głębsze wypełniała woda. Na wyższym brzegu rzeki widoczny jest także częściowo zapadnięty kanał wejściowy do nieużytkowanej nory.

Podobny przykład obserwowano na Rowie Kokockim. W korycie tego cieku, powyżej dawnego stawu retencyjnego bobry zbudowały tamę, w efekcie podpiętrzona woda wylewała się z koryta głównego i zaczęła formować 3 dodatkowe koryta boczne. Na jednym z nich powstała kolejna, niższa tama. W tym przypadku działalność bobrów przyczyniła się do rozwoju procesu awulsji i formowania się koryt bocznych.

Wzniesienie przez bobry tamy lub kilku tam usytuowanych kaskadowo na małym cieku jest najczęstszym przypadkiem ich budowlanej aktywności na obszarze podjętych badań.

\section{Przypadek 2: Budowa tam na przepustach drogowych}

Na 240-metrowym odcinku koryta Olszynki płynącej przez łąki i pastwiska, opodal wsi Olszyna, urządzono z rur betonowych o średnicy 0,8 m 12 przepustów na gruntowych drogach polnych. Obecnie tereny te nie są użytkowane. W 6 przepustach bobry przyblokowały odpływ zasłaniając 75-100\% prześwitu rur (ryc. 3B, C). Do budowy przegród wykorzystały drzewa rosnące wzdłuż brzegu cieku, gałęzie, trawę i muł.

W efekcie tamowania przepływu powyżej wspomnianych przepustów i mostu na drodze leśnej powstało 7 małych rozlewisk o powierzchni od $83 \mathrm{~m}^{2}$ do $522 \mathrm{~m}^{2}$. Tamy bobrowe wymusiły zmianę przepływu wody, która rozmywała brzegi i poszerzała koryto cieku. Doprowadzało to często do przelania się strumienia przez groble drogowe w czasie powodzi.

Ryc. 2. Tamy bobrowe na uregulowanym i pogłębionym korycie Olszynki w Młynku, A - położenie stanowiska, B - tama bobrowa na cieku, C - blokdiagram ukazujący zabudowę koryta Olszynki przez bobry i zalanie równiny zalewowej, D - tama boczna, E - widok na koryto Olszynki, tamę bobrową i wlot do kanału bobrowego, F - misy dawnych stawów na Olszynce w Młynku zalane na skutek piętrzenia bobrowego; blokdiagram ukazujący zabudowę przez bobry systemu antropogenicznych stawów i kanałów, aby zwiększyć czytelność na rysunku nie umieszczono drzew

Beaver dams on the regulated and deepened channel of the Olszynka at Młynek, A - location of site, $\mathrm{B}$ - beaver dam on the watercourse, $\mathrm{C}$ - block diagram showing the Olszynka channel built up by beavers, and the inundation of the floodplain, D - side dam, E - view of the Olszynka channel, beaver dam and entrance to the beaver channel, F - basins of old ponds on the Olszynka at Młynek, flooded by beaver damming; block diagram showing beaver constructions built in the system of anthropogenic ponds and channels; trees are omitted for the sake of clarity of the picture 

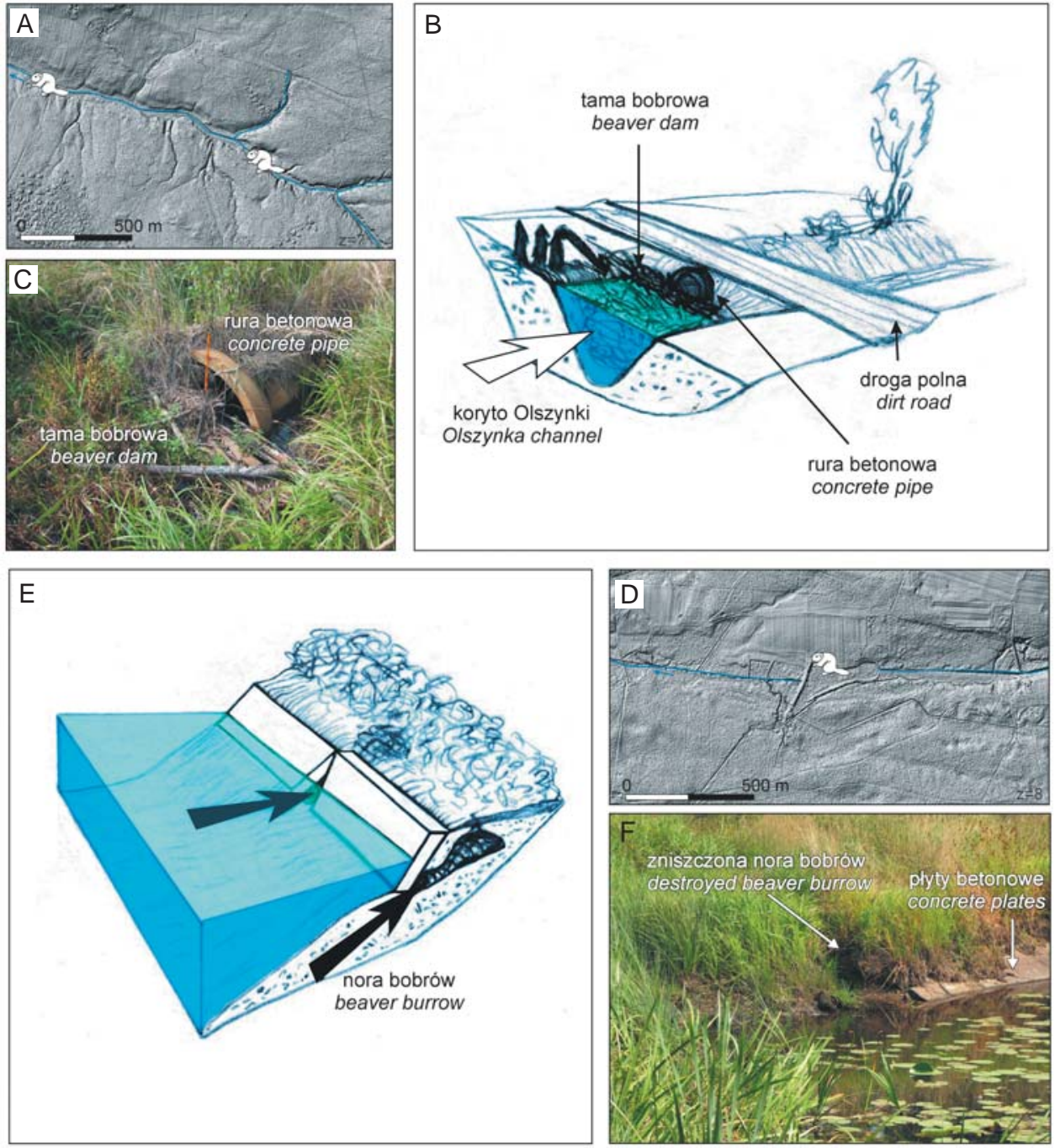

Ryc. 3. Piętrzenia wód Olszynki na przepustach pod gruntowymi drogami polnymi w Olszynie A - położenie stanowiska, B - blokdiagram ukazujący tamę bobrową opartą na betonowej rurze przepustu, C - przepust na Olszynce przyblokowany przez bobry, D - staw na Olszynce w Drapaczu ze stanowiskiem bobra, E - blokdiagram ukazujący ułożenie płyt betonowych, za którymi bobry zbudowały norę, F - brzeg stawu z wejściem do nory bobrowej

The damming of the Olszynka in culverts under dirt roads at Olszyna, A - location of the site, $\mathrm{B}$ - block diagram showing a beaver dam founded upon the concrete pipe in the culvert, $\mathrm{C}$ - a culvert on the Olszynka blocked by beavers, D - a pond on the Olszynka at Drapacz with a beaver site, $\mathrm{E}$ - block diagram showing the arrangement of concrete slabs behind which beavers built a burrow, F -bank of a pond with the entrance to a burrow 


\section{Przypadek 3: Zasiedlanie i adaptacja dawnych kanałów wodnych (młyń- skich, hutniczych)}

Nie wykorzystywane systemy wodne dawnych zakładów hutniczych i młynów znajdują się dziś w fazie destrukcji. Kanały zarastają, co spowalnia w nich przepływ wody. Na brzegach kanałów rosną zazwyczaj szpalery drzew i zarośla wierzbowe. W okresach suszy, przy niskich stanach wody przepływ zwykle ustaje, wówczas woda na pewnych odcinkach stagnuje. Niektóre kanały są zasilane także wodą z rowów melioracyjnych. Z koryt rzecznych w ujściowe odcinki tych kanałów przedostają się bobry i budują w ich obrębie tamy oraz zakładają żerowiska.

Taki przypadek zanotowano w sąsiedztwie młyna wodnego w Kuźnicy Nowej nad Liswartą. Bobry eksploatują w tym miejscu zasobniejszy w wodę odcinek młyńskiego kanału dolnego (odpływowego) (ryc. 1E). Zbudowały przegrodę i podpiętrzyły wodę, dzięki czemu ukryły wejście do nory usytuowanej w brzegu młynówki. W sąsiedztwie widoczne są ślizgi - ścieżki bobrowe przypominające rynny. Bobry założyły żerowiska także na brzegach pobliskiego koryta Liswarty, w strefie do 200 m od ujścia młynówki.

Podobną działalność bobrów zaobserwowano w Krywałdzie nad Małą Panwią - w miejscu dawnej osady hutniczej, położonej pośrodku dużego kompleksu lasów. Od końca XVIII w. do około 1870 r. pracowała tam fryszerka żelaza (Musioł i Płuszczewski, 1960). Jedyną pozostałością działalności przemysłowej jest fragment kanału wodnego o długości $420 \mathrm{~m}$ i szerokości około $4 \mathrm{~m}$ (ryc. 1G). W 1997 r. zlikwidowano ostatnie zabudowania osady. Kanał ma połączenie z korytem rzeki tylko przez ujście, wlot do kanału jest zasypany. Nad kanałem oraz między kanałem i korytem Małej Panwi znajdują się żerowiska bobrów. Bobry przez pewien czas znajdowały schronienie w obrębie kanału. Dzisiejsze ślady wskazują jednak na to, że przed kilku laty opuściły to lokum. Obecnie próbują budować tamy w korycie Małej Panwi, jednak piętrzenia są niszczone przez wezbrania rzeki. Obok solidniejszego fragmentu tamy bobrowej, który przetrwał napór wody, odrzucony nurt rzeki rozmył piaszczysty brzeg tworząc podcięcie erozyjne.

\section{Przypadek 4: Zasiedlanie brzegów stawów retencyjnych}

Staw na Olszynce w Drapaczu o powierzchni 1,8 ha do czasu powodzi w 2013 r. pełnił funkcję retencyjno-rekreacyjną. Powódź dokonała częściowych zniszczeń przelewu burzowego tego stawu, jednak utrzymał się tam poziom wody na tyle wysoki, że rezydują w nim bobry. Umiejętnie wykorzystały one zdyslokowane płyty betonowe chroniące stromy brzeg stawu przed abrazją, urządzając wejście do nory w rozwarciu między płytami (ryc. 3E, F). Obok widoczny jest ślizg bobrowy, a na brzegu stawu, ponad wylotem wentylacyjnym nory znajduje 
się gęstwina jeżyn częściowo zgryziona przez bobry. Młode pędy jeżyn stanowią wiosną urozmaicenie diety tych zwierząt.

\section{Przypadek 5: Piętrzenie wody w korycie rzeki i zalanie mis dawnych stawów}

Szczególną sytuację odnotowano w osadzie Młynek. Bobry spiętrzyły tam wodę w uregulowanym korycie Olszynki, analogicznie jak w przypadku 1. Zatapiając dno doliny zalały jednocześnie misy trzech dawno nieużytkowanych, zarośniętych drzewami stawów. Misy stawów znajdują się po obu stronach koryta Olszynki i są oddzielone od niego groblami (ryc. 2F). Tama bobrowa spiętrzyła wodę w korycie potoku do wysokości górnej partii wałów przykorytowych. Z misami stawów bobry połączyły to spiętrzenie kanałami, a miejsca po dawnych, zniszczonych urządzeniach spustowych ze stawów „uzupełniły” swoimi tamami.

\section{Przypadek 6: Zasiedlenie brzegu zbiornika przeciwpożarowego}

W pobliżu osady leśnej Czołka, powyżej przepustu drogowego został przed laty urządzony na Olszynce zbiornik i punkt czerpania wody do celów przeciwpożarowych. Bobry założyły norę w jego brzegu (ryc. 4). Na kanale wentylacyjnym nory zgromadziły stertę ściętych gałęzi i patyków.

Powódź w 2010 lub w 2013 r. zniszczyła konstrukcję piętrzącą punktu czerpania i poziom wody w zbiorniku znacznie się obniżył. Nora z odsłoniętym wejściem została przez bobry porzucona. Obecnie bobry zasiedlają rozlewisko położone kilkadziesiąt metrów powyżej punktu czerpania wody, podparte zbudowaną przez siebie tamą o wysokości $1 \mathrm{~m}$.

\section{Przypadek 7: Naprawa dawnej grobli stawu}

Najbardziej spektakularnymi przykładami wykorzystania przez bobry antropogenicznych budowli hydrotechnicznych do swoich potrzeb są przypadki naprawy zniszczonych grobli dawnych stawów retencyjnych.

Jedna z grobli znajduje się na Leńcy koło Boronowa. W Boronowie od początku XVI w. do lat 1860. działały 2 huty żelaza, zaopatrywane w wodę piętrzoną w stawach zlokalizowanych na Liswarcie. Dodatkowymi rezerwuarami wody na wypadek dłuższych okresów suszy były: staw młyński usytuowany na źródłowym odcinku Liswarty, staw młyński na Leńcy, a także położone powyżej młyna 2 zbiorniki retencyjne z betonowymi śluzami zbudowane około 1830 r. (Gołąbek, 2004) i jeden mniejszy staw retencyjny z groblą ziemną. Grobla ta, o długości $24 \mathrm{~m}$ i wysokości $1 \mathrm{~m}$, została dawno temu w dwóch miejscach przerwana, prawdopodobnie przez powódź. Staw nie był użytkowany przynajmniej od drugiej połowy XIX w.

W 1995 r. do Leńcy w pobliżu dawnego stawu młyńskiego została wsiedlona jedna para bobrów. W ciągu 20 lat gryzonie skolonizowały odcinek doliny na długości $2,4 \mathrm{~km}$, budując 5 dużych tam ze stawami zajmującymi dno doliny i kil- 

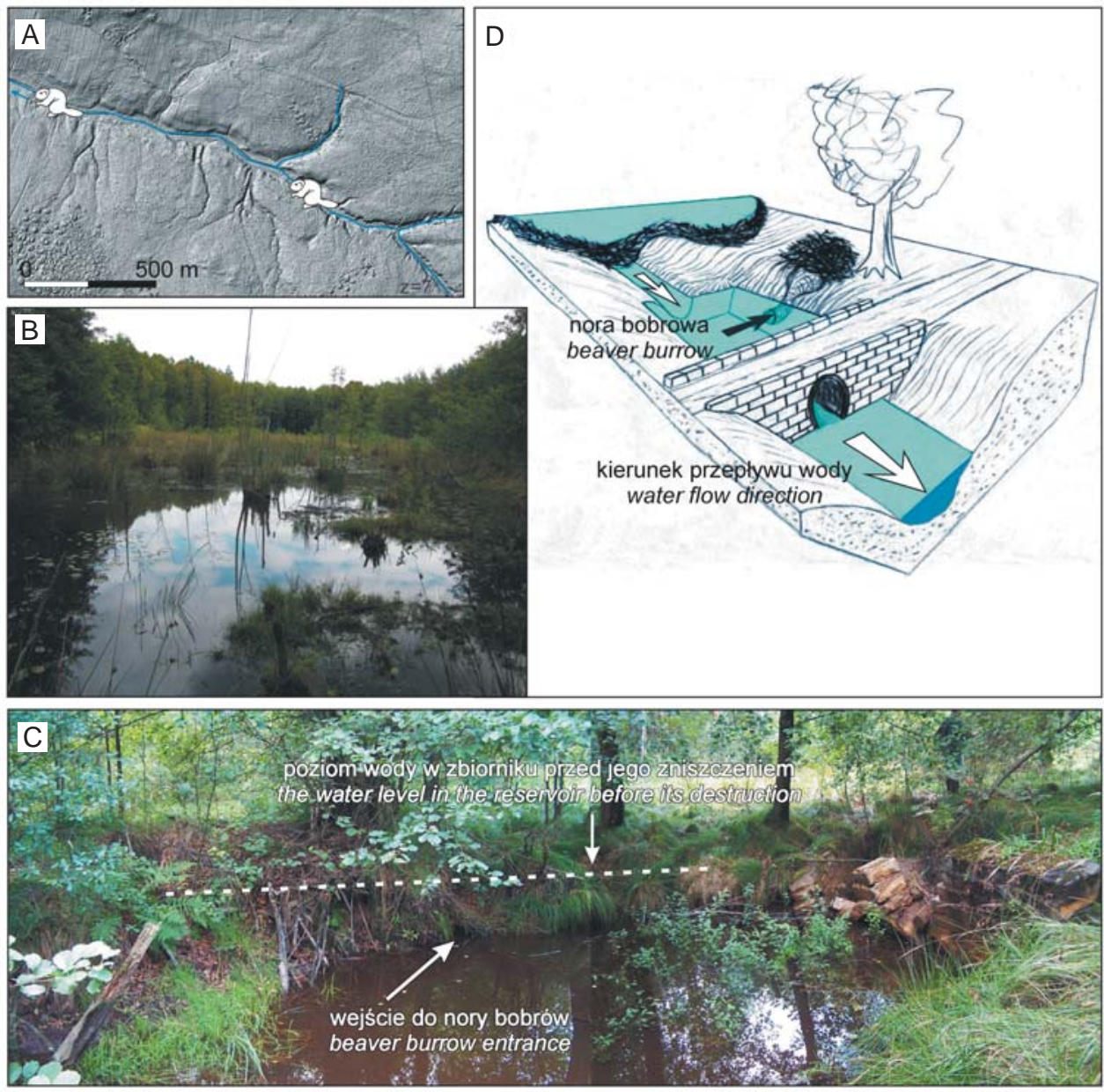

Ryc. 4. Tama i staw bobrowy na Olszynce w okolicy Czołki powyżej leśnego, przeciwpożarowego zbiornika wodnego

A - położenie stanowiska, B - staw bobrowy powyżej zbiornika ppoż, C - pozostałości zbiornika ppoż ze śladami działalności bobrów, D - blokdiagram ukazujący położenie stawu i nory bobrowej w stosunku do zbiornika ujęcia wody

Beaver pond and dam on the Olszynka near Czołka, above the forest-located pond established for fire-fighting purposes

A - location of the site, B - beaver pond above the reservoir, C - remains of the fire-fighting tank with traces of beaver activities, D - block diagram showing the location of the beaver burrow and pond in relation to the water intake reservoir

ka mniejszych zapór w korycie. Bobry naprawiły także wspomnianą zniszczoną groblę ziemną, zapełniając ubytki gałęziami, patykami oraz mułem (ryc. 5D, E) i spiętrzyły wodę odtwarzając staw o powierzchni około $2160 \mathrm{~m}^{2}$. Drzewa, które wyrosły w misie stawu są stopniowo ścinane i zgryzane przez bobry. 

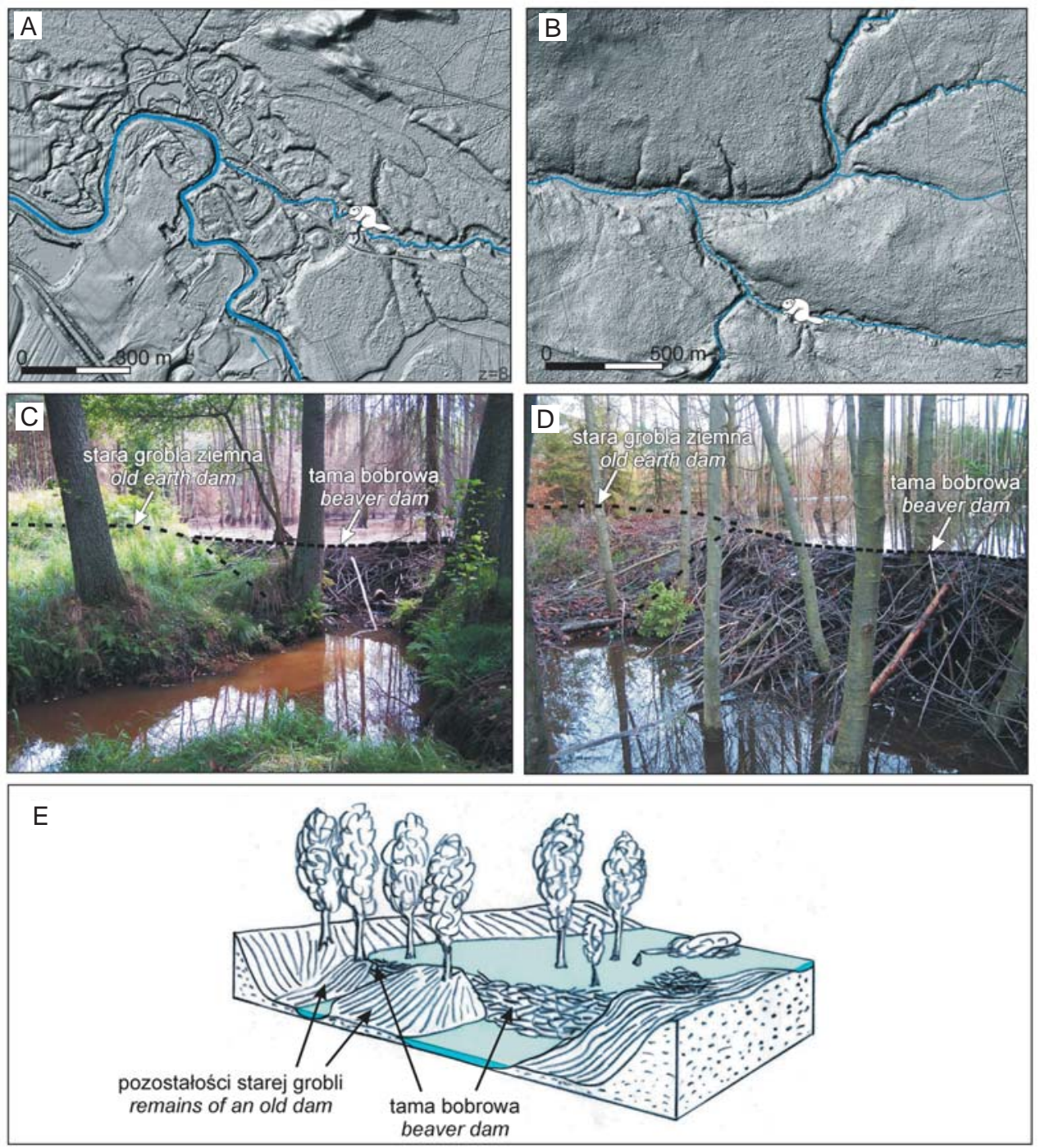

Ryc. 5. Pozostałości dawnych grobli czołowych leśnych stawów retencyjnych z „plombami” dobudowanymi przez bobry

A - na Rowie Kokockim, B - na Leńcy, C - tama bobrowa wbudowana w pozostałości starej, czołowej grobli ziemnej stawu na Rowie Kokockim, D - tamy bobrowe wbudowane w pozostałości starej grobli ziemnej stawu na Leńcy, E - blokdiagram ukazujący starą groblę czołową stawu retencyjnego „naprawioną” przez bobry

Remains of old embankments of retention ponds located in forest and with gaps plugged by beavers

A - on the Rów Kokocki, B - on the Leńca, C - beaver dam built in the remains of an old earth pond embankment on the Rów Kokocki, D - beaver dam built in the remains of an old earth pond embankment on the Leńca, E - block diagram showing an old embankment of the retention pond "repaired" by beavers 
Drugi przykład naprawy grobli czołowej dużego stawu zaobserwowano na Rowie Kokockim, około 500 m powyżej jego ujścia do Małej Panwi (ryc. 5C). Ośmiometrową wyrwę w dawnej grobli ziemnej, o długości $83 \mathrm{~m}$ i wysokości 2,5 m, bobry zabudowały gałęziami i mułem, tworząc tamę o wysokości 1,5 m. Spiętrzając wodę utworzyły staw o powierzchni około $7300 \mathrm{~m}^{2}$, a w starej grobli wykopały norę. Powstanie rozlewiska spowodowało zalanie upraw leśnych i zamieranie drzew, w związku z tym, w korpus tamy bobrowej zostały wprowadzone rury przelewowe, obniżając poziom wody w stawie o około $0,5 \mathrm{~m}$.

\section{Dyskusja}

Przeprowadzone badania wskazują, że bobry zakładają swoje siedliska raczej na dopływach Małej Panwi i Liswarty, tj. rzekach 3-4 rzędu. W dolinach tych rzek dogodne warunki stwarzają bobrom płytkie koryto (0,3-0,6 m) o niewielkim spadku (2,2-6,7 $\left.\mathrm{m} \mathrm{km}^{-1}\right)$ i piaszczystym lub piaszczysto-mulistym dnie oraz rosnące w pobliżu drzewa liściaste. W przypadkach większych rzek (Mała Panew, Liswarta) bobry wykorzystują chętnie boczne kanały i młynówki. Na podobne preferencje bobrów wskazuje A. Gurnell (1998), odnotowując kolonie zakładane częściej wokół starorzeczy i innych zbiorników wodnych na równinie zalewowej, przylegającej do dużych koryt rzecznych.

Tamy budowane przez bobry w korycie rzeki głównej często ulegają zniszczeniu. Badania W. McComb i innych (1990) przeprowadzone na rzekach 3 rzędu wskazują na dużą skuteczność osadniczą bobrów związaną z ich zdolnościami adaptacyjnymi. Zdaniem N. Suzuki i W. McComb (1998) optymalne warunki do budowy tam znajdują bobry na ciekach o szerokości 3-4 m. Takie warunki stwarzają bobrom Rów Kokocki, Leńca i Olszynka.

Dogodnymi miejscami do lokalizacji tam bobrowych są zwężenia dolin i koryt lub wypłycenia cieków, gdzie niewielki wzrost piętrzenia tworzy relatywnie duży zalew (Kobojek, 2005; Grygoruk, 2008). Naturalne zwężenia den dolin były korzystne do wznoszenia budowli piętrzących także przez człowieka, np. w przypadku Rowu Kokockiego duże znaczenie miały wydmy schodzące do doliny. Po zaniechaniu na tych terenach działalności przemysłowej, wykorzystującej obiekty hydrotechniczne, inicjatywę przejęły bobry. Najliczniejsze ślady ich działalności zaobserwowano w dolinie Leńcy i Olszynki na odcinkach zalesionych. Nie miało przy tym dla bobrów znaczenia, że koryta cieków zostały przebudowane przez człowieka. Zwierzęta instynktownie wykorzystały relikty obiektów hydrotechnicznych. Interesującym przypadkiem jest „naprawa” przez bobry starych grobli stawów antropogenicznych na Rowie Kokockim i na Leńcy.

W literaturze mniej uwagi poświęca się zagadnieniu zasiedlania przez bobry dolin rzecznych przekształconych przez człowieka. Interesujących danych dostarczają badania prowadzone na Litwie. Bobry z powodzeniem adaptują się tam do zmienionych antropogenicznie środowisk (Ulevičius i inni, 2009, 2011). 
Zwierzęta użytkują rzeki, potoki, stawy, ale najczęstszymi dla nich siedliskami są kanały i rowy melioracyjne w lasach, stanowiące ponad 80\% tamtejszej sieci hydrograficznej (Ulevičius i inni, 2011). Aż 36\% stawów bobry zbudowały właśnie na tych rowach, renaturyzując je (Kesminas i inni, 2013).

Ciekawych przykładów na dostosowywanie się bobrów do zmienionego antropogenicznie środowiska dolin rzecznych dostarczają badania E. Kobojek (2005, 2013). Stwierdziła ona m.in., że na znacznie przekształconym przez człowieka odcinku rzeki Rawki, o uregulowanym korycie z jazami, bobry do osiedlania się zachęcały istniejące tam stawy rybne. W innym miejscu, w dolinie Bzury, bobry budując tamy zagospodarowały podmokły obszar dawnej młynówki (Kobojek, 2005). Tworząc stawy w systemie kaskadowym, zwierzęta te silnie oddziałują na funkcjonowanie rzek (Gurnell, 1998).

Stawy młyńskie, hutnicze i rybne, które istniały w przeszłości na obszarze badań pełniły ważną rolę jako obiekty małej retencji wody w zlewniach Małej Panwi i Liswarty, lecz także wpływały na procesy korytowe. Oddziaływanie historycznych piętrzeń na procesy hydrogeomorfologiczne w dolinach rzecznych jest znane m.in. z badań Z. Podgórskiego (2004), S. Downward i K. Skinner (2005), R. Walter i D. Merritts (2008) czy J. Pizzuto i M. O'Neal (2009). R. Walter i D. Merritts (2008) uważają, że tamy XVII-XIX-wiecznych młynów były w tym czasie głównym czynnikiem sedymentacji w dolinach rzecznych wschodniej części Stanów Zjednoczonych. Także likwidacja młynów w XX w. miała wpływ na procesy fluwialne - wzrosło wówczas tempo erozji brzegów (Pizzuto i O'Neal, 2009). Stawy bobrowe mają podobne znaczenie jak niewielkie stawy antropogeniczne (Dalbeck i Weinberg, 2009). Według D. Butlera i G. Malansona (1995) typowa tama bobrowa ma 15-70 m długości i 1-2 m wysokości. A. Gurnell (1998) stwierdza, że wysokość tam rzadko przekracza 1,5 m. Tempo sedymentacji w stawach bobrowych to 2-39 cm/rok (Butler i Malanson, 2005). Dzięki bobrom kontynuowane są do pewnego stopnia niektóre funkcje hydrologiczne pełnione niegdyś przez antropogenicznie przekształcone systemy rzeczne.

Na badanym terenie bobry „zagospodarowały się” najczęściej na obszarach, które pod względem ekonomicznym nie są współcześnie cenne dla człowieka. Na małych ciekach leśnych, takich jak Olszynka czy Leńca, bobry przekształciły 28-35\% długości koryt rzecznych. Wyniki badań prowadzonych w Ameryce Północnej dowodzą, że bobry modyfikują 20-40\% całkowitej długości cieków 2 i 3 rzędu, a w czasie lata ich rozlewiska mogą magazynować nawet 30\% wody zlewni (Czerepko i inni, 2009). W sierpniu 2015 r., kiedy panowała susza hydrologiczna w południowej Polsce, w podpiętrzonych korytach i w stawach bobrowych Leńcy i Olszynki była zretencjonowana woda, podczas gdy niżej koryta były prawie suche.

Bobry niwelują niekorzystne zmiany antropogeniczne w środowisku (Pollock i inni, 2007, 2014; Burchsted i inni, 2010). Stawy bobrowe są miejscem sedymentacji osadów mineralnych i organicznych oraz swego rodzaju mechaniczną 
„oczyszczalnią wód” (Butler i Malanson, 1995; Cirmo i Driscoll, 1993; Szpikowska i Szpikowski, 2012). Tamy bobrowe moga powodować analogiczne skutki, jak 2-5 m wysokości tamy młynów wodnych (Walter i Merritts, 2008; Levine i Meyer, 2014). Budując tamy na rowach melioracyjnych i porzuconych piętrzeniach antropogenicznych bobry przyczyniają się do tworzenia lub odtwarzaja pierwotne siedliska wodno-błotne (Grygoruk i Nowak, 2014; Pollock i inni, 2014), a uregulowanym korytom rzecznym przywracają bardziej naturalny charakter.

W dolinach badanych przez autorów rzek bobry odtworzyły istniejące w przeszłości stawy antropogeniczne. Powyżej stawów bobrowych (Rów Kokocki) lub między stawami (Olszynka, Leńca) zmniejsza się spadek koryta, wzrasta jego krętość i tworzą się koryta boczne. Miejscami predysponowanymi do dzielenia przepływu wody i tworzenia wielokorytowych odcinków cieków stają się najczęściej kanały transportowe bobrów stanowiące obniżenia w brzegu koryta i wałach przykorytowych. Dzieje się to nawet w fazie początkowej ich kształtowania. Przez te kanały woda wraca także z koryta bocznego do głównego. Jest to proces charakterystyczny dla cieków z niskimi brzegami (Kesminas i inni, 2013). Zdaniem geomorfologów tamy bobrowe ułatwiają proces awulsji i tworzenia wielokorytowego przepływu (m. in. Makaske, 2001; John i Klein 2004; Polvi i Wohl, 2012, 2013). W czasie podjętych badań zaobserwowano takie przypadki na małych ciekach leśnych (Rowie Kokockim, Leńcy i Olszynce).

W wyniku wzrostu populacji bobrów dochodzi jednak także do aneksji przez nie terenów wciąż intensywnie użytkowanych przez człowieka, co prowadzi do konfliktów. Na obszarze badań przykładem takiej sytuacji było tworzenie zalewisk powyżej przepustów w nasypach kolejowych. Tam aktywność zwierząt stwarzała zagrożenie dla infrastruktury i ruchu pociągów, dlatego zaszła potrzeba przeniesienia ich w inne miejsce. W niektórych przypadkach wyłączono jednak z intensywnego użytkowania wybrane obiekty hydrotechniczne zastępując je innymi (np. stawy leśne czy punkty czerpania wody).

\section{Podsumowanie}

Przeprowadzone badania wskazują, że bobry dobrze radzą sobie z zasiedlaniem antropogenicznie zmienionej sieci wód powierzchniowych na terenach rolnych i leśnych. Od czasu reintrodukowania bobrów w zlewnie Małej Panwi i Liswarty w latach 1990. ich populacja znacząco się zwiększyła.

Bobry najczęściej trafiały na odcinki dolin rzecznych, w których człowiek zaniechał intensywnej gospodarki, tam szybko przystosowały środowisko do swoich potrzeb. Gryzonie wykorzystały instynktownie relikty zabudowy hydrotechnicznej (groble, kanały) dawnych zakładów produkcyjnych i włączały je do systemu swoich budowli.

$\mathrm{Na}$ badanych odcinkach dolin rzecznych rozpoznano 12 stanowisk bobrowych, na których zwierzęta zbudowały tamy ze stawami lub niewielkimi rozle- 
wiskami. Konstrukcje bobrowe budowane były w różnym czasie (w latach 19942015) i różny jest ich stan zachowania. Wzrost populacji, dostępność zasobów pokarmowych bądź zniszczenia powodziowe sprawiły, że bobry przenosiły się w górę i w dół cieków.

W uregulowanych korytach rzecznych oraz w obrębie dawnych obiektów hydrotechnicznych wyróżniono 7 charakterystycznych przypadków „inżynieryjnej” działalności bobrów. Są to: budowa tam bobrowych w korytach rzecznych i dawnych kanałach wodnych (młyńskich, hutniczych), „naprawa” dawnych grobli stawów antropogenicznych i zalanie ich mis, wykorzystanie przepustów drogowych do wznoszenia tam, zasiedlanie brzegów stawów i niewielkich zbiorników retencyjnych specjalnego przeznaczenia (przeciwpożarowe).

Bobry zasiedlają raczej małe doliny rzeczne bocznych dopływów Liswarty i Małej Panwi. Stanowiska bobrowe na głównych rzekach były zlokalizowane na bocznych kanałach wodnych.

Stawy bobrowe są obiektami wspomagającymi tzw. małą retencję wód. Efekt retencyjny tych stawów był szczególnie widoczny w okresie suszy w sierpniu 2015 r. Na Leńcy i Olszynce zaobserwowano, że w czasie suszy w stawach bobrowych i podpiętrzonych korytach rzek nie brakowało wody, gdy niższe odcinki koryt były prawie suche.

Bobry restytuują ekosystemy, stopniowo zbliżając je do naturalnych. Stawy bobrowe retencjonujące wodę tworzą nowe siedliska dla innych gatunków i tym samym stwarzają warunki do wzrostu bioróżnorodności w przekształconych antropogenicznie dolinach rzecznych. W sąsiedztwie stawów bobrowych tworzą się podmokłe i zabagnione łąki.

W przypadkach istotnych konfliktów między gospodarczą działalnością człowieka i obecnością bobrów na badanym obszarze albo rezygnowano z użytkowania obiektów zajętych przez bobry, albo przenoszono zwierzęta w inne miejsce.

Autorzy składają podziękowania Profesorowi Andrzejowi Czylokowi za dyskusje i cenne uwagi dotyczące ekologii bobrów.

Badania zrealizowano w ramach projektu OPUS 2011/01/B/ST10/00548 finansowanego przez Narodowe Centrum Nauki.

\section{Piśmiennictwo / References}

Bagniewski Z., 1990, Obozowisko mezolityczne z doliny Baryczy, Pobiel 10, woj. leszczyńskie, Studia Archeologiczne, 19, PWN, Warszawa.

Bejenaru L., Stanc S., Popovici M., Balasescu A., 2015, Beavers (Castor fiber) in the past: Holocene archaeological evidence for beavers in Romania, International Journal of Osteoarchaeology, 25, 4, s. 375-391.

Bereszyński A., Homan E., 2007, Występowanie bobra europejskiego (Castor fiber Linnaeus, 1758) w Poznaniu, Nauka Przyroda Technologie, 1, 2, \#38; http://www.npt.up-poznan.net/tom1/zeszyt2/art_38.pdf. 
Błędzki L.A., Bubier J.L., Moulton L.A., Kyker-Snowman T.D., 2011, Downstream effects of beaver ponds on the water quality of New England first- and second-order streams, Ecohydrology, 4 (5), s. 698-707.

Burchsted D., Daniels M., Thorson R., Vokoun J., 2010, The river discontinuum: Applying beaver modifications to baseline conditions for restoration of forested headwaters, BioScience, 60, 11, s. 908-922.

Butler D.R., Malanson G.P., 1995, Sedimentation rates and patterns in beaver ponds in a mountain environment, Geomorphology, 13, s. 255-269.

Butler D.R., Malanson G.P., 2005, The geomorphic influences of beaver dams and failures of beaver dams, Geomorphology, 71, s. 48-60.

Cech B., 2004, Water power in 16th century precious metal production in the Gastein district of the Austrian Alps, Mining History: The Bulletin of the Peak District Mines Historical Society, 15, 4/5, s. 77-82.

Cirmo C.P., Driscoll C.T., 1993, Beaver pond biogeochemistry: acid neutralizing capacity generation in a headwater wetland, Wetlands, 13, s. 277-292.

Ciszewski D., Kramarz P., Malik I., Owczarek P., Zygmunt E., 2005, Geomorfologiczne skutki funkcjonowania i degradacji sztucznych progów wodnych, Czasopismo Geograficzne, 76, 4, s. 329-343.

Coles J.M., Orme B.J., 1983, Homo sapiens or Castor fiber?, Antiquity, 57, s. 95-102.

Czech A., 2005, Analiza dotychczasowych rodzajów i rozmiaru szkód wyrządzanych przez bobry (Castor fiber) oraz stosowanie metod rozwiazywania sytuacji konfliktowych, Instytut Ochrony Przyrody PAN, Kraków; http://www.bobry.pl/docs/szkody_bobry.pdf (16.04.2016 r.).

Czech A., 2010, Bóbr - budowniczy i inżynier. Fundacja Wspierania Inicjatyw Ekologicznych, Kraków; http://bobry.pl/docs/bobr-budowniczy-i-inzynier.pdf (16.04.2016 r.).

Czerepko J., Wróbel M., Boczoń A., Sokołowski K., 2009, The response of ash-alder swamp forest to increasing stream water level caused by damming by the European beaver (Castor fiber L.), Journal of Water and Land Development, 13A, s. 249-262.

Dalbeck L., Weinberg K., 2009, Artificial ponds: a substitute for natural Beaver ponds in a Central European Highland (Eifel, Germany), Hydrobiologia, 630, s. 49-62.

Downward S., Skinner K., 2005, Working rivers: the geomorphological legacy of English freshwater mills, Area, 37, 2, s. 138-147.

Dynowska I., 1971, Typy reżimów rzecznych w Polsce. Zeszyty Naukowe Uniwersytetu Jagiellońskiego, Prace Geograficzne, 28, Kraków.

Dzięciołowski R., 2004, Bóbr europejski, [w:] P. Adamski, R. Bartel, A. Bereszyński, A. Kepel, Z. Witkowski (red.), Gatunki zwierząt (z wyjątkiem ptaków). Poradniki ochrony siedlisk i gatunków Natura 2000 - podręcznik metodyczny, T. 6, Ministerstwo Środowiska, Warszawa. s. 457-462.

Dzięciołowski R., Gozdziewski J., 1999, The reintroduction of European beaver, Castor fiber, in Poland, [w:] P.E. Busher, R.M. Dzięciołowski (red.), Beaver Protection, Management, and Utilization in Europe and North America, Kluwer Academic/Plenum Publishers, New York, s. 31-37.

Fajer M., 2003, Budowle wodne jako element krajobrazu w dorzeczu Liswarty, Prace Komisji Krajobrazu Kulturowego PTG, 2, s. 78-86.

Fajer M., 2004, Morfologiczne i geologiczne uwarunkowania rozwoju doliny Liswarty w holocenie, Prace Wydziału Nauk o Ziemi UŚ, 32, Sosnowiec.

Fajer M., 2014, Watermills - a forgotten river valley heritage - selected examples from the Silesian voivodeship, Poland, Environmental \& Socio-economic Studies, 2, 2, s. 1-9. 
Gibson P.P., Olden J.D., 2014, Ecology, management, and conservation implications of North American beaver (Castor canadensis) in dryland streams, Aquatic Conservation: Marine and Freshwater Ecosystems, 24, s. 391-409.

Gilewska S., 1972, Wyżyny Śląsko-Małopolskie, [w:] M. Klimaszewski (red.), Geomorfologia Polski, t. 1, Polska południowa-góry i wyżyny, PWN, Warszawa, s. 232-340.

Gołąbek D., 2004, Dawne hutnictwo i górnictwo w okolicy Boronowa, Rada Gminy Boronów, Boronów.

Grygoruk M., 2008, Metodyka szacowania objętości retencyjnej stawów bobrowych oraz ich oddziatywania na stosunki wodne zlewni leśnych, Studia i Materiały Centrum Edukacji Przyrodniczo-Leśnej, 10, 2 (18), s. 162-172.

Grygoruk M., Nowak M., 2014, Spatial and temporal variability of channel retention in a lowland temperate forest stream settled by european beaver (Castor fiber), Forests, 5, s. 2276-2288.

Gurnell A.M., 1998, The hydrogeomorphological effects of beaver dam-building activity, Progress in Physical Geography, 22, s. 167-189.

Halley D.J., Rosell F., Saveliev A., 2012, Population and Distribution of Eurasian Beaver (Castor fiber), Baltic Forestry, 18 (1), s. 168-175.

Janiszewski P., Misiukiewicz W., 2012, Bóbr europejski, Castor fiber, BTL, Warszawa, http://www.bobrowniczy.pl/bobrowy.pdf (16.04.2016 r.).

John S., Klein A., 2004, Hydrogeomorphic effects of beaver dams on floodplain morphology: avulsion processes and sediment fluxes in upland valley floors (Spessart, Germany), Quaternaire, 15, 1-2, s. 219-231.

Kesminas V., Steponėnas A., Pliūraitė V.,Virbickas T., 2013, Ecological impact of eurasian beaver (Castor fiber) activity on fish communities in Lithuanian trout streams, Annual Set The Environment Protection, 15, s. 59-80.

Kobojek E., 2005, Środowiskowe skutki reintrodukcji bobra (Castor fiber) $w$ dolinie Rawki Przegląd Geograficzny, 77, 3, s. 383-396.

Kobojek E., 2013, Wptyw dziatalności bobrów na lokalne procesy fluwialne w wybranych rzekach Równiny Łowicko-Błońskiej, Acta Universitatis Lodziensis, Folia Geographica Physica, 12, s. 17-32.

Kukulak J., 2000, Origin of laminated sediments in alluvium of the upper San valley in the Bieszczady Mountains, Eastern Carpathians, Geochronometria, 18, s. 47-52.

Levine R., Meyer G.A., 2014, Beaver dams and channel sediment dynamics on Odell Creek, Centennial Valley, Montana, USA, Geomorphology, 205, s. 51-64.

Makaske B., 2001, Anastomosing rivers: a review of their classification, origin and sedimentary products, Earth-Science Reviews, 53, s. 149-196.

Malik I., 2004, Rola kłód w ksztattowaniu dna koryta rzeki meandrującej na przykładzie Małej Panwi (Równina Opolska), Czasopismo Geograficzne, 75, 4, s. 255-274.

Malik I., 2006, Contribution to understanding the historical evolution of meandering rivers using dendrochronological methods: example of the Mala Panew River in southern Poland, Earth Surface Processes and Landforms, 31, s. 1227-1245.

Malik I., 2008, Dendrochronologiczny zapis wspótczesnych procesów rzeźbotwórczych ksztattujacych stoki $i$ doliny rzeczne wybranych stref krajobrazowych Europy Środkowej, Wydawnictwo Uniwersytetu Śląskiego, Katowice.

Malik I., Wistuba M., Opała M., Franek M., Woskowicz-Ślęzak B., Mańczyk G., Tyrol C., 2015, Historical water-powered ferrous metallurgy reconstructed from tree-rings and lacustrine deposits (Mała Panew Basin, Southern Poland), Geochronometria, 42, s. 79-90. 
McComb W.C., Sedell J.R., Buchholz T.D., 1990, Dam-site selection by beavers in an eastern Oregon basin, Great Basin Naturalist, 50, 3, s. 273-281.

Musioł L., Płuszczewski S., 1960, Wykaz zakładów dawnego hutnictwa żelaza na Górnym Śląsku od XIV do potowy XIX w., Studia z Dziejów Górnictwa i Hutnictwa, 5.

Pizzuto J., O'Neal M., 2009, Increased mid-twentieth century riverbank erosion rates related to the demise of mill dams, South River, Virginia, Geology, 37, s. 19-22.

Plan ochrony Parku Krajobrazowego „Lasy nad Górna Liswarta”, Załacznik do uchwaty nr 278/XXII/2013 Rady Miejskiej w Woźnikach z dnia 25 marca 2013 r., Woźniki, http://www.bip.wozniki.pl/files/sites/3137/wiadomosci/198748/files/plan_ochrony_ parku_krajobrazowego_lasy_nad_gorna_liswarta.pdf (16.01.2016 r.).

Plan urządzenia lasu dla nadleśnictwa Koszęcin, Obręby: Boronów, Koszęcin, Zielona na okres gospodarczy od 1 stycznia 2010 r. do 31 grudnia 2019 r. Ogólny opis lasów nadleśnictwa. Biuro Urządzania Lasu i Geodezji Leśnej Oddział w Krakowie.

Podgórski Z., 2004, Wptyw budowy i funkcjonowania mtynów wodnych na rzeźbę terenu $i$ wody powierzchniowe Pojezierza Chetminskiego i przylegtych części dolin Wisty i Drwęcy, Wydawnictwo UMK, Torun.

Pollock M.M., Heim M., Werner D., 2003, Hydrologic and geomorphic effects of beaver dams and their influence on fishes, [w:] S.V. Gregory, K. Boyer, A. Gurnell (red.), The Ecology and Management of Wood in World Rivers, American Fisheries Society Symposium 37, s. 213-233.

Pollock M.M., Beechie T.J., Jordan C.E., 2007, Geomorphic changes upstream of beaver dams in Bridge Creek, an incised stream in the interior Columbia River basin, Earth Surface Processes and Landforms, 32, s. 1174-1185.

Pollock M.M., Beechie T.J., Wheaton J.M., Jordan C.E., Bouwes N., Weber N., Volk C., 2014, Using beaver dams to restore incised stream ecosystems, BioScience, 64, 4, s. 279-290.

Polvi L.E., Wohl E., 2012, The beaver meadow complex revisited - the role of beavers in post-glacial floodplain development, Earth Surface Processes and Landforms, 37, s. 332-346.

Polvi L.E., Wohl E., 2013, Biotic Drivers of Stream Planform: Implications for Understanding the Past and Restoring the Future, BioScience, 63, 6, s. 439-452.

Popiołek K., 1965, Górnośląski przemyst górniczo-hutniczy w drugiej połowie XIX w., Śląski Instytut Naukowy, Katowice-Kraków.

Rocznik Statystyczny Rzeczpospolitej Polskiej 2015, GUS, Warszawa.

Rosell F., Bozsér O., Collen P., Parker H., 2005, Ecological impact of beavers Castor fiber and Castor canadensis and their ability to modify ecosystems, Mammal Review, 35, 3-4, s. 248-276.

Statystyczne Vademecum Samorzadowca 2015, http://stat.gov.pl/statystyka-regionalna/statystyczne-vademecum-samorzadowca/ (16.01.2016 r.).

Suzuki N., McComb W.C., 1998, Habitat classification models for beaver (Castor canadensis) in the streams of the Central Oregon coast range, Northwest Science, 72, 2, s. 102-110.

Szczypek T., 1977, Utwory i procesy eoliczne w pótnocnej części Wyżyny Ślaskiej, Prace Naukowe UŚ, 190.

Szpikowska G., Szpikowski J., 2012, Wtaściwości fizykochemiczne wód rozlewisk bobrowych w Dolinie Kłudy (górna Parsęta), Monitoring Środowiska Przyrodniczego, 13, s. 95-102.

Ulevičius A., Jasiulionis M., Jakštienè N., Žilys V., 2009, Morphological alteration of land reclamation canals by beavers (Castor fiber) in Lithuania, Estonian Journal of Ecology, 58, 2, s. 126-140. 
Ulevičius A., Kisielytė N., Jasiulionis M., 2011, Habitat use and selectivity by beavers (Castor fiber) in anthropogenic landscape, Ekologija, 57, 2, s. 47-54.

Walter R.C., Merritts D.J., 2008, Natural streams and the legacy of water-powered mills, Science, 319, s. 299-304.

Witek M., 2012, Wptyw zabudowy hydrotechnicznej na wspótczesne kształtowanie rzeźby koryt rzek ziemi kłodzkiej, Landform Analysis, 19, s. 91-102.

Wright J.P., Jones C.G., Flecker A.S., 2002, An ecosystem engineer, the beaver, increases species richness at the landscape scale, Oecologia, 132, s. 96-101.

Żurowski W., 1992, Building activity of beavers, Acta Theriologica, 37, 4, s. 403-411.

Mapy:

Special-Karte von Südpreussen, D. Gilly, skala 1:150 000, 1802-1803 r., Berlin; http://igrek.amzp.pl/ (7.01.2016 r.).

Topographische Spezialkarte von Mitteleuropa, G.D. Reymann, skala 1:200 000, 1832-1870 r., Berlin; http://igrek.amzp.pl/ (7.01.2016 r.).

Topograficzna karta Królestwa Polskiego, skala 1:126 000, 1839-[1843] r., Kwatermistrzostwo Generalne Wojska Polskiego, Warszawa; http://igrek.amzp.pl/ (7.01.2016 r.).

Topographische Karte (Messtischblatt), skala 1:25 000, 1870-1889 r., Berlin; http://igrek.amzp.pl/ (7.01.2016 r.).

Mapa Szczegótowa Polski, skala 1:25 000, 1929-1939 r., WIG, Warszawa; http://igrek.amzp.pl/ (7.01.2016 r.).

Mapy topograficzne, skala 1:10 000, CODGiK, Warszawa; http://www.geoportal.gov.pl/dane/skany-map-topograficznych (5.01.2016 r.).

Ortofotomapy z lat 1996, 2003 i 2009; http://mapy.orsip.pl/imap (5.01.2016 r.).

Ortofotomapa z 2012 roku; http://geoportal.gov.pl/ (5.01.2016 r.).

[Wpłynęło: maj; poprawiono: wrzesień 2016 r.]

\section{MARIA FAJER, IRENEUSZ MALIK, JAN MACIEJ WAGA, MAŁGORZATA WISTUBA, BEATA WOSKOWICZ-ŚLĘZAK}

\section{CONTEMPORARY ADAPTATION OF ANTHROPOGENICALLY-TRANSFORMED RIVER VALLEYS BY EUROPEAN BEAVERS CASTOR FIBER (EXAMPLES FROM POLAND'S OPOLE PLAIN AND WOŹNIKI-WIELUŃ UPLAND)}

Many of Poland's valleys resemble those of the Mała Panew and Liswarta (and their tributaries) in featuring the remains of old hydrotechnical infrastructure formerly used by gristmills, steel plants and sawmills. As the importance of water as their main source of energy declined, such earlier industrial plants were gradually closed down, with a steady process of deterioration of hydrotechnical infrastructure then set in train.

Beavers were reintroduced into the catchments of the Mała Panew and Liswarta in the 1990s, with the rodents immediately commencing with the adaptation of anthropogenically-transformed habitats to better meet their needs.

Against this background, research was conducted to determine:

- the number of beaver sites in the river valleys in question, and especially the number within or near disused items of hydrotechnical infrastructure, 
- the ways in which beavers have "managed" the infrastructural items in question,

- the impact beavers' activities have had on the environment in the valleys studied.

The locations and functions of old items of hydrotechnical infrastructure were determined by reference to archival maps. To assess beavers' activities, 6 sections of watercourse of lengths $0.5-7 \mathrm{~km}$ were selected, with locations of beaver dams and ponds, as well as other traces of activity by the animals, documented and described.

With a view to findings being summarized, distinctions were drawn between various methods of adaptation of former hydrotechnical objects by beavers, i.e. 1 - dams built in the channels of regulated rivers, 2 - dams built in culverts, 3 - former millrace/ water channels (used by gristmills or ironworks) occupied and adapted, 4 - banks of retention ponds occupied, 5 - waters in river channels dammed and basins of old ponds flooded, 6 - banks of ponds serving fire-fighting purposes occupied, 7 - former pond dams restored.

Beavers can adapt successfully to - and also themselves adapt - anthropogenicallytransformed environments in river valleys. In this regard, the rodents were found to be more eager to occupy the tributaries of the Mała Panew and Liswarta than the rivers themselves. The valleys offer suitable conditions for beavers, given channels that are shallow (of 0.3-0.6 m), slightly sloping $(2.2-6.7 \mathrm{~m} / \mathrm{km}$ ), with sandy or sandy-sludgy bottoms, as well as access to deciduous trees growing nearby. Along the Mała Panew and Liswarta themselves, beavers make use of side channels and millraces. Most numerous traces of beavers' activity were to be observed along forested stretches of the Leńca and Olszynka Valleys, which are found to have been transformed by beavers along 28-35\% of their lengths. The animals made instinctive use of relic items of hydrotechnical infrastructure, with an interesting case involving the "restoration" by beavers of old embankments of anthropogenic ponds on the Rów Kokocki and the Leńca.

Above beaver ponds (on the Rów Kokocki) or between ponds (on the Olszynka and Leńca), reduced channel slope and increased channel sinuosity contribute to the creation of side channels. Along these sections, transport channels made by beavers are vulnerable to avulsion and the emergence of multi-channel sections of watercourses.

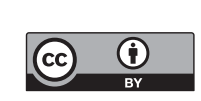


http://rcin.org.pl 